\title{
3 Mundos da morte: Representação e transição do morrer em Tolstói
}

João Paulo Campos

Este artigo foi originalmente elaborado como trabalho final do curso de "Antropologia da Morte", ministrado no $1^{\circ}$ Semestre de 2014 pela Profa. Karenina Andrade, a quem agradeco pelos comentários e sugestões sobre o texto, além das discussões em sala de aula.

Resumo: Este estudo introduz uma discussão sobre a obra $A$ morte de Ivan Ilitch, de Lev Tolstói, considerando a experiência de sua personagem principal como formalização de uma transição paradigmática nas formas de relação com a morte na Rússia. A presente interpretação busca lançar novos olhares sobre esta obra canônica, demonstrando como o drama de Ivan Ilitch revela um momento em que a Rússia czarista se encontrava num processo de transição rumo a um contexto de medicalização da morte individualizada, características do processo civilizatório europeu. A obra explora um momento, parafraseando Michel Vovelle (1987), de reviravolta da "sensibilidade coletiva" entre os russos, momento em que formas de ver e experimentar a vida e a morte se encontravam em debate e transformação. Dessa maneira, Tolstói justapõe dois mundos distintos - a tradição campesina russa e o mundo burguês ocidental - numa narrativa tensionada, levando-nos a uma experiência próxima em relação a um importante dilema enfrentado pela sociedade russa oitocentista: a importação de ideias e modos de vida ocidentais através de uma elite cosmopolita frente a tradição campesina russa, fortemente influenciada pela vida comunitária e religiosa. Palavras-chave: Mundos da morte; Medicalização da morte; Literatura Russa; Leon Tolstó
Abstract: This paper starts a discussion about Leo Tostoy's "The Death of Ivan Ilyich", considering it's main character's experience as formalization of a paradigmatic transition in terms of the way death was dealt in Russia. The present interpretation aims to bring a new perspective on this masterpiece, stressing how the drama of Ivan Ilych reveals the moment when Tsarist Russia faced a transition towards the medicalization of an individual's death, which is a peculiarity of Europe's civilizing process. Tolstoy's work explores times, quoting Michel Vovelle (1987), of overturn in "collective sensibility" amongst the russian society, times in which the ways of facing and experiencing life and death were in debate and suffering several changes. This way, Tolstoy overlaps two distinct worlds - the russian's countryside tradition and the bourgeois western world - in a strained narrative that takes us to a substantial dilemma which russian society was struggling through during the nineteenth century: the importation of western ideas and ways of life by a cosmopolitan elite faced with the russian countryside ethos, which is strongly influenced by the religious and communitary life.

Key-words: Death Worlds; Medicalization of death; Russian Literature; Leo Tolstoy 
Birth, and copulation, and death. That's all the facts when you come to brass tacks;

Birth, and copulation, and death.

T. S. Eliot. Sweeney Agonistes (1932)

\section{Preâmbulo}

A morte é um tema que foi explorado por diversos artistas em épocas distintas. Na literatura, mais especificamente na literatura russa oitocentista, a temática da morte encontra uma prosa dura e pesada e, assim, foi explorada de maneira singular: realista, cética, dolorosa e sem requintes românticos. Desde Gogol, passando por Dostoiévski, Turgueniev, Gorki e Tolstói, a morte e a relação das personagens com o morrer surgem nessas narrativas, de maneira manifesta ou latente. "Afinal, vamos todos morrer, esse é o nosso costume estúpido, sim, irmão" (Gorki, 2007, p. 109).

Esses autores ambicionavam, através de suas obras, expressar dramas, sentimentos e loucuras - para dizer o mínimo de pessoas comuns: do mujique das frias estepes russas, do preceptor endividado, do estudante na penúria, do funcionário público, do homem do subsolo, enfim, das pessoas mais variadas que habitavam a Rússia czarista e matizavam as cidades e vilarejos por onde esses escritores realizavam as suas andanças e observações. Entre os elementos comuns da vida dessas personagens arquétipos, encontra-se a morte.

O suicídio de Anna Kariênina no romance homônimo de Tolstói, a morte de Marmeladov e da velha usurária em Crime e castigo de Dostoiévski e, para terminar por aqui, as preocupações, angústias e indagações do príncipe Míchkin em relação a pena de morte - alusão à obra de Victor Hugo, $O$ último dia de um condenado - em $O$ idiota, também de Dostoiévski, demostram, em companhia de outros vários exemplos da história da literatura russa, a inclinação desses escritores pelos mais ínfimos detalhes do morrer.

Não obstante, a morte vem perdendo presença na vida cotidiana. A morte e o morrer se transformaram, a partir do século XVIII e de maneira mais intensa nos séculos XIX e XX, em categorias culturais proibidas, da ordem do indizível e impensável. Como escreveu Geoffrey Gorer, "em todos os lugares e em todas as épocas existem palavras e ações que, quando deslocados do contexto, podem produzir choque, embaraço social e riso" (Gorer, 2003, p. 49, tradução minha). Porém, a morte no mundo contemporâneo não só causa desconforto e "embaraço social", ela literalmente perdeu o seu lugar em diversos contextos e sistemas culturais e se tornou o interdito absoluto, o tabu por excelência, constituindo "a nova categoria de obsceno no mundo atual" (Vovelle, 1987, p. 59). Não falamos na morte, sentimentos um verdadeiro desconforto perante a ideia ou a materialização da morte, suicídios são amiúde escondidos por familiares e foram excluídos das mídias. Hoje, recalcamos o morrer - e tudo relacionado ao processo de morrer - como em outros tempos recalcávamos a sexualidade e a natalidade. A morte e, com ela, o luto, passaram da vida pública para a ordem do privado. Citando novamente Gorer: 
1 Sobre a ideia da presença dos mortos no mundo dos vivos, ver Oexle (1996).

${ }^{2}$ Note-se que este argumento é, segundo Freud, uma conjectura.
Na maior parte dos últimos duzentos anos, o coito e (ao menos em meados da era Vitoriana) a natalidade eram os termos "inomináveis" da tríade das experiências humanas básicas que "são o que importa quando você encara os fatos" em torno da qual muitas fantasias privadas e pornografias semi-clandestinas foram erigidas. Durante a maioria desse período a morte não era um mistério, exceto no sentido de que a morte é sempre um mistério. Crianças eram encorajadas a pensarem sobre a morte, as suas próprias mortes e as edificantes ou cautelosas mortes na cama de outrem. Pode ter existido um raro indivíduo que, no século XIX com sua alta taxa de moralidade, não presenciou ao menos uma morte real, bem como cumprir seu respeito aos "belos corpos", funerais eram as maiores ocasiões de exposição para a classe trabalhadora, a classe média e para os aristocratas. O cemitério era o centro de toda velha vila e eles eram proeminentes em quase todas as cidades. Já era bastante tarde no século XIX quando a execução de criminosos parou de ser um feriado público como também um aviso público (Gorer, 2003, p. 50).

Vemos que, em outras épocas, a morte era um fato bastante presente na vida das pessoas, pertencendo à ordem da vida pública. Não obstante, os mortos têm sido paulatinamente excluídos do mundo dos vivos. Neste processo, notadamente ocidental, o mundo dos mortos foi dissociado do mundo dos vivos e, portanto, os mortos não têm mais presença $a^{l}$ na vida, a não ser pela memória do falecido. De qualquer forma, o morrer foi deixado de lado e, mesmo que de maneira inconsciente, nós nos julgamos imortais.

Assim, o luto foi "esvaziado", somos obrigados a experimentar nossa melancolia e sofrimento às escondidas, pelos cantos. A tolerância pública em relação ao luto e à melancolia diminuiu drasticamente e, como resultado dessa transformação de mentalidade, não podemos externalizar nosso sofrimento, a carga dramática do luto se esvaziou. Sofremos no âmbito privado e com tempo limitado, pois, depois de certo tempo de pranteio o que era luto se transforma em melancolia e, assim, uma patologia se instaura. Em termos freudianos, a ligação que a pessoa tinha com o objeto perdido, motivo do pranteio pela perda da pessoa amada e querida, durante o luto, é paulatinamente substituída por outras pulsões libidinais na medida em que o ego assimila que o objeto não existe mais (o termo não existe é, para os nossos fins, digno de nota) e de que o indivíduo que ficou está vivo. O desfruto das "satisfações narcísicas" no mundo dos vivos vai dissipando o estado de luto, daí se segue a gradual, porém efetiva, superação do luto $^{2}$. A não superação dessa condição institui o estado patológico da melancolia e o melancólico, nas sociedades em que a morte não é suportada, não tem lugar, o que o leva muitas vezes ao ostracismo. Segundo Freud:

O luto normal também supera a perda do objeto e enquanto dura ele absorve igualmente todas as energias do ego. Por que, depois que passou, não há indícios de que se produziu nele a condição econômica para uma fase de triunfo? Acho impossível responder de imediato a essa objeção. Ela chama nossa atenção para o fato de que sequer podemos dizer por que meios econômicos o luto realiza sua tarefa; mas talvez aqui possa ser útil uma conjectura. Em cada uma das recordações e situações de expectativa que mostram a libido ligada ao objeto perdido, a realidade traz à tona o seu veredicto de que o objeto não existe mais e o ego, por assim dizer, indagado se quer compartilhar esse destino, deixa-se determinar 
${ }^{3}$ Em seu relato, Didion descreve a situação na qual o médico que estava encarregado de seu marido fica receoso de dar a notícia da e $\mathrm{o}$ assistente social que acompanhava Didion intervém com o objetivo de quebrar a tensão e diz: "Tudo bem, ela é uma cliente bastante equilibrada".

${ }_{4}$ Esta tensão surge em diversos romances russos, por exemplo, perpassa toda a obra de Tolstói e Dostoiévski, além de ser uma questão central no terceiro volume da trilogia autobiográfica de Gorki, intitulada Minhas Universidades. Para além da literatura, ver Gomide (2013) pela soma de satisfações narcísicas dadas pelo fato de estar vivo, e desfaz sua ligação com o objeto aniquilado. Podemos imaginar que esse desligamento se dá tão lenta e gradualmente, que ao terminar o trabalho também se dissipou o gasto que ele requeria (Freud, 2001, p. 77-79).

Vivemos sob o imperativo da felicidade e da atividade (ou produtividade) onde a tristeza e a inutilidade são demonizadas e expulsas do convívio social "aceitável" e "saudável". Dessa forma, somos inclinados inconscientemente a buscar a felicidade plena e a diversão para assim nos tornarmos indivíduos plenos. Qualquer menção a morte destrói essa harmonia tecida minuciosamente através no dia-a-dia de homens e mulheres. Temos que botar em prática uma economia sentimental na qual os dois maiores artifícios são a mentira e a contenção das emoções. Essas constrições nos inclinam, lembrando o primoroso relato de Joan Didion em seu $O$ ano do pensamento mágico, a tornarmo-nos todos "clientes bastante razoáveis" "3, isto é, o imperativo da felicidade nos obriga a conter nossas emoções fortes e "selvagens" (Elias, 1994; 2001), para não pecarmos contra a felicidade coletiva.

Nota-se que, nesse contexto, a noção de indivíduo impera na formação da pessoa ocidental e a busca da felicidade é individual, assim como a morte solitária nos leitos de hospitais. Não obstante, este processo não ocorreu em todas as partes do mundo e, na Rússia, se deu de maneira singular, envolvendo choques e debates intensos em torno da incorporação de categorias e formas de vida ocidentais no mundo russo, movimento possível por uma elite intelectual ociosa e cosmopolita, estudantes e movimentos revolucionários que, transitando entre os dois mundos, ambicionavam transformar a Rússia, então czarista e cristã, aos moldes de exemplos como a Revolução Francesa e ou a Revolução Industrial ${ }^{4}$. Intensificam-se os debates que envolvem termos-chave como "civilização", "progresso", "modernização" e “industrialização", assim como a repulsa deles e do que eles representam - por exemplo, a repulsa das consequências da "máquina a vapor", vista como símbolo da indústria ocidental e, portanto, estrangeira.

O século XIX foi uma época cultural e politicamente turbulenta entre os russos, após reformas de czares, cisões nos regimes autoritários e a formação da intelligentsia russa, a cultura e a nacionalidade russas eram construídas e reconstruídas através de projetos antagônicos: eslavófilos, ocidentalistas, nacionalistas a favor do regime, niilistas radicais, socialistas utópicos etc. Cada grupo tinha uma posição e a defendia arduamente nos periódicos e na vida pública russa, lutando contra seus inimigos "de praça" e a censura do regime czarista. Como declara Bruno Barreto Gomide:

A virada do século XVIII para o XIX trouxe alterações cruciais no modo como se pensava o país A influência da Revolução Francesa, a profusão de novas correntes intelectuais na corte de Alexandre (que reinou de 1801 a 1825), os diferentes ventos românticos e, sobretudo, a campanha napoleônica e o ano-chave de 1812 aprofundaram uma cisão dentro da nobreza russa que já vinha se gestando desde a segunda metade do reinado de Catarina II (de 1762 a 1796), tal fratura no interior da elite intelectual diminuta está na origem da camada social conhecida como intelligentsia, conceito que é tão fundamental para a história intelectual russa quanto de difícil

Dossiê Literatura e Memória

Arquivos do CMD, Volume 3 N.2. Ago/Dez 2015 
${ }^{5}$ Sobre a intelligentsia, ver Gomide (2013) e Berlin (1988).

6 Uma interessante e divertida referência sobre esses atores do processo de modernização da Rússia é o caso de Turguêniev, ridicularizado por Dostoiévski em carta, na qual o último diz que ele se transformou em um legítimo alemão. Para compreender melhor este caso e a posição de Dostoiévski frente ao europeus, ver Dostoiévski (2011).

Apesar do exemplo se referir a obra de Dostoiévski, creio com avidez que ele também é pertinente para o caso de Tolstói, uma vez que as duas obras, cristalizam e formalizam fragmentos da cultura russa dos tempos em que estes viveram, tecendo pontos de contato entre ficção e realidade social. No nosso caso, essas ideologias dominantes citadas por Joseph Frank, somadas a outras categorias civilizatórias europeias vão configurar uma forma singular de lidar com a morte através da qual pessoas de camadas sociais diferentes vão experimenta tipos de morrer distintos. definição. De modo muito sumário, e descontando-se todas as múltiplas variações pelas quais o termo passou, a intelligentsia pode ser entendida como certa categoria de pensadores e letrados que se autoatribui a missão de defender os valores culturais, e que se localiza distante tanto do "Estado" quanto do "povo" (Gomide, 2013, p. 10-11)

Dessa maneira, veremos que a mentalidade que configura as formas de lidar com a morte no "ocidente" esboçada nesta introdução não condiz inteiramente com a realidade russa. As ideias e modos de vida que penetraram na Rússia oitocentista através de camadas sociais cosmopolitas (como a supracitada intelligentsia) encontraram fortes resistências - dos eslavófilos, por exemplo, dentre os quais o mais notório entre o público brasileiro é Dostoiévski. Assim, o projeto modernizador europeu, defendido pelos ocidentalistas, não se enraizou de maneira mecânica entre os russos e, consequentemente, o "processo civilizador" e a individualização e medicalização da morte não transformaram, em um lampejo mágico, a Rússia numa sociedade aburguesada ou ocidentalizada, apesar da tentativa das classes mais abastadas e de alguns intelectuais de incorporar valores e ideais europeus ${ }^{6}$. Romances como os de Tolstói e Dostoiévski desmascaram as consequências da penetração de ideologias dominantes estrangeiras - "moralmente nocivas", para Dostoiévski, como aponta Joseph Frank - na formação da "psique russa", através da atividade intelectual da intelligentsia do país. Sobre Memórias do subsolo, de Dostoiévski ${ }^{7}$, Joseph Frank escreve que:
Cada um dos dois episódios da obra de Dostoiévski desmascara as consequências moralmente nocivas das duas ideologias dominantes, que, devido à força das ideias europeias na psique russa, constituíram um engodo para a intelligentsia do país. (O materialismo e o utilitarismo ético da década de 1860 são parodiados na primeira parte de Memórias do subsolo o socialismo utópico "humanitário" e "filantrópico" da década de 1840 é o alvo da segunda parte. (Frank, 1992, p. 39)

O problema que temos diante de nós é, portanto, o da importação de elementos estrangeiros para a configuração de uma cultura que começa a sofrer diversas investidas de uma classe intelectual emergente. Essas categorias são, como afirmou Roberto Schwarz a respeito do caso brasileiro (e russo, porém brevemente) “ideias fora do lugar" (Schwarz, 2000). A categoria "civilização" e a contenção de emoções e ideias decorrentes dela não foram incorporadas ao mundo russo mecanicamente e, portanto, o próprio morrer e as relações com a morte não são análogas às práticas mortuárias “ocidentais". Essa promiscuidade de ideologias, mentalidades, ideários importados e tradicionais e as práticas decorrentes dessa barafunda conceitual é representada de maneira primorosa na novela de Tolstói, onde o protagonista se encontra em uma posição no mínimo curiosa: no meio deste embate entre modelos de viver e morrer, Ivan Ilitch se encontra confuso, entre aceitar a morte ou afastá-la de si. Aqui se instaura um choque cultural com consequências cruciais para o drama do herói.

Considerando o que foi introduzido até aqui, este artigo propõe uma interpretação da obra A morte de Ivan Ilitch, de Lev

Dossiê Literatura e Memória 
Tostói, analisando-a como uma formalização de um importante debate da época: a tensão entre o modo de vida campesino, tradicionalmente russo, e o modo de vida burguês ocidental. Conflito que também diz respeito à morte, uma vez que este fenômeno universal faz parte de toda e qualquer vida. Não obstante esta universalidade da morte, ela é experimentada de maneiras diversas em contextos distintos. Como escreveu Michel Vovelle, "a confissão literária continua essencial para penetrar a face oculta do sentimento de morte", uma vez que "veicula imagens, os clichês, as lembranças e as heranças, as produções sem cessar distorcidas e reutilizadas do imaginário coletivo" (Vovelle, 1987, p. 63).

Para evitar mal-entendidos, categorias como "civilização" e "modernidade" serão utilizadas aqui sempre se referindo ao processo de medicalização e individualização da morte, elementos do "projeto modernizador" ocidental, através do qual a passagem da vida para a morte ocorre de maneira individualizada, isolada em leitos hospitalares sob a tutela de médicos e enfermeiros. Propõe-se aqui, a construção de um modelo heurístico através da chave conceitual dos modelos de morte "domesticada" e "medicalizada" (Ariès, 1989b).

\section{O odor da sala de estar - ou as exéquias do extinto}

Ivan Ilitch morre! Que notícia devastadora! Pois bem, e agora? "Agora, certamente receberei o posto de Stábel ou de Vínikov" (Tolstói, 2009, p. 8). Este foi o primeiro pensamento de Fiódor Vassílievitch, colega do defunto, ao receber a notícia da morte de seu companheiro de trabalho, que estivera deveras debilitado por uma doença que, por fim, foi fatal. As novas possibilidades objetivas de suas próprias vidas materiais dominaram o pensamento de todos os três colegas de Ivan Ilitch ao receberem a notícia da sua morte - Tolstói faz questão de demonstrar essa questão logo no início da novela. O contato com a morte é insuportável e precisar ser contornado. O que se segue é, de fato, uma "conversa para inglês ver"; uma discussão banal, desinteressada e confusa - que serve como mecanismo de evitar o contato com a morte de Ivan Ilitch - sobre o porquê da morte do colega, tão estimado por todos pela sua retidão de caráter e avidez labutaria. Para um leitor atento, a abertura da novela já nos diz muito sobre o que podemos esperar. Antes de mais nada, uma sensação conjuga tudo isto: o desconforto.

Dostoiévski amiúde atacava as classes altas de sua sociedade, como o alto escalão do serviço burocrático russo - do qual o herói da novela de Tolstói faz parte -, acusando-as de, através de suas aventuras cosmopolitas, fascínio com a vida "nos bulevares parisienses" e de sua displicência em relação ao passado nacional e a "verdadeira" cultura russa - cristalizada, segundo ele, e também Tolstói, na vida do homem camponês e no amor à vida e aos homens -, incorporarem visões de mundo, ideologias, instituições, enfim, modelos "modernizadores" europeus e importarem para a sua mãe Rússia, com o objetivo "progressista" de europeizar a sua cultura, motivo de diversas polêmicas entre a intelligentsia da época. Essa ojeriza em relação à Europa e, principalmente, à adaptação de costumes europeus em solo russo

Dossiê Literatura e Memória

Arquivos do CMD, Volume 3 N.2. Ago/Dez 2015 
${ }^{8}$ Sobre os modelos de relação com a morte, ver Philippe Ariès (1989b) Para uma crítica do trabalho de Ariès, ver Elias (2001). pelas "classes altas" é bem representada em uma carta, um tanto enfurecida, que Dostoiévski escreveu de Genebra, em seu segundo exílio, a um amigo, o poeta Apollon Nikolaievitch Maikov:

Não seria capaz de contar todos os meus pensamentos. Reuni inúmeras impressões desses dias. Li jornais russos e consolei-me com isso. Por vezes, senti que tantas ideias novas surgiam em mim que eu seria capaz de escrever um longo artigo sobre as relações entre Rússia e a Europa Ocidental, e sobre as classes altas da sociedade russa. Eu poderia, sem dúvida, ter escrito tanto! Os alemães enervavam-me; e nosso modo russo de viver, a vida de nossos aristocratas, a fé na Europa e na civilização na qual essas classes altas estão calcadas - tudo isso também me irritava. O incidente em Paris perturbou-me assustadoramente. Impressionantes, não, aqueles advogados de Paris que gritaram "Vive La Pologne!"- que estúpido, que nauseante, que insípido! Estou ainda mais convencido de minhas ideias do passado: a Europa não nos conhece nem um pouco, e tem uma péssima ideia sobre nós. $\mathrm{E}$ os detalhes sobre o processo contra Beresovski! Que medonho, que vago, não posso imaginar como eles puderam recompor-se de tamanhos disparates e seguir adiante! (Dostoiévski, 2011, p. 119)

Com efeito, as personagens envolvidas na cena descrita anteriormente fazem parte dessas "classes altas de nossa sociedade", calcadas na "civilização" e em todos os elementos ideológicos e conceituais decorrentes desta categoria. Com isto, a relação delas (e outras personagens) com a morte de Ivan Ilitch é crucial para entender o reflexo da imposição ou incorporação da "civilização" e "modernização" na cultura russa oitocentista.

Observando de perto as ações, pensamentos e sentimentos das personagens envolvidas no processo de adoecimento e morte de
Ivan Ilitch, percebemos nesse episódio uma crise do morrer e uma confluência de modelos de relacionamento com a morte. Nesse momento, modelos tradicionais de relação com a morte entraram em crise através do contato com o mundo ocidental em vias de higienização e medicalização da vida e da morte. O que Philippe Ariès (1989b) chamou de "morte domesticada" começa a se confundir com a interdição e o afastamento definitivo da morte no mundo dos vivos ${ }^{8}$. A morte individualizada e interdita entra na vida social russa, imposta pela influência das "classes altas" cosmopolitas. Assim, os pilares do projeto modernizador engajado pelos europeus ocidentais - a individualização e racionalização da sociedade - entram em um embate com formas tradicionais de viver e enxergar a vida e a morte. Como resultado desse contato se instaura um campo de tensões em que pessoas de camadas diferentes da sociedade russa, através da aceitação ou não da imposição estrangeira, vivem e morrem de maneiras distintas.

Dessa maneira, o horror e desconforto causados pelo contato com a ideia da morte - da morte de si, isto é, da morte como ruptura de um processo infalivelmente individual - levam a um ponto crucial da narrativa de Tolstói, no qual o autor formaliza um elemento importante da mentalidade e das atitudes frente à morte no mundo ocidental: a inclinação das pessoas a evitarem pensar em sua própria morte e, consequentemente, viverem como se fossem imortais. ““Aí está, morreu; e eu não' - pensou ou sentiu cada um" (Tolstói, 2009, p. 9). Porém, com a morte do colega surgem obrigações: 
Quanto aos conhecidos mais próximos, os assim chamados amigos de Ivan Ilitch, pensaram então involuntariamente também que precisavam, agora, cumprir umas obrigações muito cacetes, ir às exéquias, e também fazer uma visita de pêsames à viúva (Tolstói, 2009, p. 9).

Entre os três colegas de Ivan Ilitch envolvidos na conversa supracitada, Piotr Ivânovitch era o mais próximo do defunto - ou, nas palavras de Tolstói, do "extinto" - e, por esta razão, se sentiu obrigado a prestar condolências à viúva e, obviamente, à memória do amigo, com quem cursou a Faculdade de Direito. Portanto, Piotr Ivânovitch se dirige a casa do falecido companheiro e, ao atravessar o umbral de entrada, não fazia a menor ideia do que deveria fazer ou como deveria se portar nesta penosa - e confusa situação. Somente uma coisa the veio à mente: "que nesses casos nunca é demais fazer o sinal da cruz" (Tolstói, 2009, p. 10). O desajeito de Piotr Ivânovitch chega a ser cômico, eis a passagem completa:

Piotr Ivânovitch entrara naquela casa sem saber, como sempre acontece, o que deveria fazer ali. Sabia uma coisa: que nesses casos nunca é demais fazer o sinal da cruz. Não tinha muita certeza se era necessário também inclinar-se, e, por isso, escolheu uma solução intermediária: entrando no quarto, começou a persignar-se e como que a inclinar-se um pouco. Ao mesmo tempo, examinava o quarto, na medida em que lhe permitiam os movimentos que fazia com a cabeça e os braços. Dois jovens, um dos quais ginasiano, provavelmente sobrinhos do falecido, saíam do quarto persignando-se. Uma velhinha estava parada, imóvel. E uma senhora com sobrancelhas estranhamente erguidas murmurava-lhe algo. Um sacristão de sobrecasaca, decidido, animado, lia alguma coisa pisando com passos leves diante de Piotr Ivânovitch, o ajudante de copeiro Guerássim polvilhou o chão com algo. Vendo isto, Piotr Ivânovitch sentiu no mesmo instante um odor ligeiro do cadáver em decomposição [...] Piotr Ivânovitch não cessava de fazer o sinal da cruz e inclinar-se ligeiramente, numa direção intermediária entre o caixão, o sacristão e os ícones colocados a um canto da mesa. Depois, quando esse movimento de se persignar lhe pareceu prolongado demais, interrompeu-o e pôs-se a examinar o defunto (Tolstói, 2009, p. 10-11).

O desconforto e desajeito desta personagem frente à morte do amigo nos leva à crise de formas tradicionais de relação com a morte, através dos quais existiam "scripts" socialmente reconhecidos e reproduzidos de relação com o morrer e de conduta diante a morte. Esse modus operandi, fortemente enraizado na cultura tradicional russa, oferecia um leque de ações simbólicas para situações relativas ao morrer, através das quais se construía uma práxis fúnebre mais consolidada e, provavelmente, um tanto automática. Na cena supracitada Piotr Ivânovitch realmente não sabe o que fazer. Nada é concreto, não existe um "script" definido de como se portar diante do defunto, como prantear o "extinto" e como prestar condolências à viúva e parentes próximos. A confusão e o desconforto frente à morte indicam uma espécie de aversão à morte por Piotr Ivânovitch, típica das culturas de sociedades pós-industriais, disciplinadamente higienizadas, onde a morte se transformou em uma forte interdição obscena. Segundo Norbert Elias:

Rituais religiosos de morte podem provocar nos crentes sentimentos de que as pessoas estão pessoalmente preocupadas com eles, o que é sem 
${ }^{9} \mathrm{Um}$ contraponto interessante a essa maneira de experimentar o pranteio é trabalhado por Marce Mauss em seu texto A expressão obrigatória dos sentimentos obrigatória dos sentimentos
(rituais fúnebres orais australianos), 1926. dúvida a função real desses rituais. Fora deles, morrer é no presente uma situação amorfa, uma área vazia no mapa social. Os rituais seculares foram esvaziados de sentimento e significado; as formas seculares e tradicionais de expressão são pouco convincentes. Os tabus proíbem a excessiva demonstração de sentimentos fortes, embora eles possam acontecer. [...] $\mathrm{O}$ crescente tabu da civilização em relação à expressão de sentimentos espontâneos e fortes trava suas línguas e mãos. E os viventes podem, de maneira semiconsciente, sentir que a morte é contagiosa e ameaçadora; afastam-se involuntariamente dos moribundos. (Elias, 2001, p. 36-37).

Assim, nos contextos em que prevaleciam a influência de ideias e atitudes do mundo ocidental perante a morte, situações fúnebres - como a que Piotr Ivânovitch vivenciou - foram esvaziadas de sentido e de carga dramática, passando a serem experimentadas pelas pessoas de maneira racional e com o máximo de decoro possível' ${ }^{9}$. No caso russo, o caos interior de Piotr Ivânovitch expressa uma confusão e choque entre ideias e atitudes tradicionais e "progressistas" - para usar o termo empregado por Dostoiévski para designar o ethos civilizatório europeu representada, por sua vez, nesse "não saber o que fazer". Seguindo novamente Elias, nesses contextos:

A convenção social fornece as pessoas umas poucas expressões estereotipadas ou formas padronizadas de comportamento que podem tornar mais fácil enfrentar as demandas emocionais de tal situação. Frase convencionais e rituais ainda estão em uso, porém mais pessoas do que antigamente se sentem constrangidas em usá-las, porque parecem superficiais e gastas. As fórmulas rituais da velha sociedade, que tornavam mais fácil enfrentar situações críticas como essa, soam caducas e pouco sinceras para muitos jovens; novos rituais que reflitam o padrão corrente dos sentimentos e comportamentos, que poderiam tornar a tarefa mais fácil, ainda não existem (Elias, 2001, p. 32)

O constrangimento decorrente do ritual fúnebre não termina por aí. Com efeito, ele se intensifica quando a viúva de Ivan Ilitch Prascóvia Fiódorovna, convida o colega do marido defunto para uma conversa privada. Na sala de visitas, sozinhos e longe do odo desagradável do cadáver em decomposição, a viúva ensaia uma conversa com Piotr Ivânovitch de maneira desajeitada, tentando de todas as maneiras manter a postura que sua posição impõe: de luto, ela deve prantear o morto, porém, de maneira contida e com o menor grau de dramatização possível. Ela tenta demonstrar seu respeito pelo falecido marido e manter as aparências para, subitamente, expressar as suas verdadeiras intenções. Estas, apesar de todo o teatro, são unicamente pragmáticas, monetárias. De um lado, a viúva fala desajeitadamente, de outro, Piotr Ivânovitch, evidentemente constrangido com a situação e com os pensamentos voltados para a possibilidade de uma noite agradável com os amigos no carteado, tenta se ajeitar, sem sucesso, no pufe escangalhado. Aqui novamente o desconforto é evidente:

Entrando na sua sala de visitas forrada de cretone corde-rosa e com um abajur sombrio, sentaram-se à mesa: ela no divã, e Piotr Ivânovitch sobre um pufe baixinho, de molas estragadas, e que se amoldava de modo incorreto quando ele se sentava. Prascóvia Fiódorovna quis avisá-lo que se sentasse numa cadeira, mas achou tal aviso não condizente com o seu estado e mudou de ideia. Sentando-se no pufe, Piotr Ivânovitch lembrou-se de quando Ivan Ilitch estava

Dossiê Literatura e Memória 
${ }^{10}$ Veremos que, diferentemente de seu colega Piotr Ivânovitch, Ivan Ilitch se encontra entre esses dois universos simbólicos, apresentandose como uma personagem marcada pela ambiguidade e complexidade de sentimentos e atitudes frente à morte. Voltarei a esse ponto nas considerações finais deste artigo.

${ }_{11} \mathrm{O}$ desenvolvimento das ciências médicas e da saúde pública, juntamente com o aumento da segurança pública e o afastamento da ideia da morte, concorreram para a formação das ilusões de imortalidade do mundo moderno. Sobre os impactos da higienização da vida, ver COSTA (1999). instalando esta sala de visitas e aconselhara-se com ele justamente sobre o cretone cor-de-rosa com folhas verdes. Dirigindo-se para o divã e ao passar junto à mesa (de modo geral, toda a sala de visitas estava cheia de móveis e bibelôs), a viúva teve a renda da sua mantilha preta enganchada nos entalhes da mesa. Piotr Ivânovitch soergueu-se, para desvencilhar a renda, e o pufe libertado debaixo dele começou a agitar-se e a empurrá-lo. A viúva pôs-se sozinha a ajeitar a sua renda, e Piotr Ivânovitch tornou a sentar-se, comprimido debaixo de si o pufe em rebelião. Mas a viúva não conseguiu libertar a renda inteira, e Piotr Ivânovitch levantou-se mais uma vez, o pufe tornou a rebelar-se e até emitiu um estalido. Quando tudo isso, ela tirou um lenço limpo de cambraia e chorou. (Tolstói, 2009, p. 12-13).

De fato, tudo o que Piotr Ivânovitch queria era sair logo daquele lugar, deixando a morte para trás e abraçar sua ilusória imortalidade, passando a noite com os colegas entre bebidas e rodadas de uíste (jogo de cartas muito comum entre os russos). E foi o que ele fez.

A morte é, de maneira semiconsciente, distanciada por Piotr Ivânovitch, para o mais longe possível de sua vida normal. Se pensar na morte já estava sendo penoso, vivenciar situações ao lado dela era insuportável. Essa personagem está, portanto, imersa em um sistema simbólico que nega de maneira radical o inevitável, isto é, a finitude humana ${ }^{10}$

\section{Rim móvel ou ceco? A dúvida que não era metódica}

Cogito ergo sum. Esta expressão é crucial para compreender o processo de modernização empreendido pela Europa ocidental e posiciona Descartes como um dos grandes guias dessa movimentação. Assim, o racionalismo está na base do processo que fez surgir as categorias "moderno" e "modernização". Como aponta Max Weber, as sociedades "ocidentais" foram passando, desde os romanos, por um crescente processo de racionalização de seus campos, o que desembocou na ascensão do sistema capitalista de produção, além de transformações estruturais nas mentalidades e atitudes perante a vida e a morte. Cada vez mais as pessoas guiam suas ações a partir de lógicas teleológicas e de cálculo, deixando de lado as emoções e a tradição. Este argumento pode ser complementado pela visão de Elias sobre o processo civilizador, através do qual os indivíduos contêm cada vez mais seus instintos animalescos e sentimentos, rejeitando também, assim, a sexualidade em um primeiro momento e, mais tarde, as coisas da morte. A relação com a morte - e com a vida - é, portanto, esvaziada de drama e sentimentos fortes. A racionalidade individual deve, seguindo esta lógica, reger todos os ambientes da vida e da morte.

A racionalização das esferas da sociedade, sob a bandeira do progresso e desenvolvimento, atinge também a área da saúde e do conhecimento. As ciências médicas, portanto, se desenvolvem a partir desse processo e se tornam instrumento de postergação da morte por excelência ${ }^{11}$. No campo da morte, o médico substitui o padre para tratar do enfermo e tentar estender vidas a todo custo e o hospital se torna o ambiente dos últimos dias dos moribundos, em lugar do ambiente doméstico. A "solidão dos moribundos" substitui

Dossiê Literatura e Memória

Arquivos do CMD, Volume 3 N.2. Ago/Dez 2015 
${ }^{12}$ Eufemismos e narrativas com o objetivo de encobrir o fato da morte e o horror engendrado pelo processo de morrer entre sociedade higienizada e medicalizada surgem no dia a dia das pessoas, a palavra morte tenta ser afastada do cotidiano das pessoas, sendo substituída por expressões mais leves, principalmente na presença de crianças.

13 Nesta expressão Tolstói demonstra claramente a dimensão racional e o afastamento com que os médicos tratam a doença e a morte. Não parecem mais humanos se relacionando com humanos. que realmente importa é o tratamento através de uma práxi profissional predeterminada. A função e a posição sobrepujam a humanidade comum entre médico e paciente. Dessa forma, essa a antiga reunião pública diante o enfermo e o isolamento dos velhos e doentes surge como fato comum da vida dos que vão "dessa para melhor"12. Dessa forma, o morrer também se torna privado e individual, as crianças não tomam conhecimento de sua finitude e, além disso, são mantidas afastadas não só da ideia da morte, mas dos próprios moribundos. Isto se confirma como elemento crucial das sociedades "higienizadas" e "disciplinadas". Todos evitam o moribundo.

Tolstói trabalha de maneira brilhante o processo de ostracismo dos moribundos e o enraizamento da medicina na Rússia como uma esfera superior e sagrada da vida social, um grupo fechado em seu hermetismo e conhecimentos próprios calcados no conhecimento racional e positivo do corpo e da vida humana. Assim, Ivan Ilitch, após diversas crises nervosas devido a sua doença e, "depois de uma briga em que Ivan Ilitch fora particularmente injusto" com sua esposa, antecedida por diversos diagnósticos confusos e medidas ortodoxas e alternativas pelo doente, Prascóvia Fiódorovna "lhe disse que, se estava doente, devia tratar-se, e exigiu que fosse consultar um médico famoso" (Tolstói, 2009, p. 37). De fato, o nosso herói cedeu às demandas de sua conjugue, mas sem muito alento:

Tudo se passou como se esperava, isto é, como sempre acontece nessas ocasiões: a espera, um ar importante e artificial, doutoral, que já conhecia, aquele mesmo que ele sabia que tinha no tribunal, as batidas no paciente, a auscultação, as perguntas que exigiam respostas formuladas de antemão e, ao que se parece, desnecessárias, a expressão significativa, que sugeria o seguinte: basta que você se submeta a nós, e havemos de arranjar tudo, sabemos sem nenhuma dúvida como arranjá-lo, temos um padrão único para todas as pessoas. Tudo era exatamente igual ao que se sucedia no tribunal. Assim como ele assumia certa expressão para falar com os acusados, o médico famoso também assumia determinada expressão (Tolstói, 2009, p. 37)

Assim como a esfera jurídica, tão familiar a Ivan Ilitch, o mundo da medicina ocidental se trancou em sua "jaula de ferro" pegando emprestado o conceito de Max Weber - hermética, onde só os iniciados com competências incorporadas por um processo especial têm o direito legítimo de expressar veredictos sobre os objetos próprios do conhecimento do campo. A experiência desalentadora de Ivan Ilitch continua, não sem certo sarcasmo de Tolstói:

$\mathrm{O}$ doutor dizia: isto e mais aquilo indicam que o senhor tem no seu interior isto e mais aquilo; mas se isto não se confirmar pela pesquisa disto e de mais aquilo, teremos que supor no senhor isto e mais aquilo. E supondo-se que tenha isto e mais aquilo, então... etc. Somente uma questão tinha importância para Ivan Ilitch: a sua condição apresentava perigo? Mas o doutor não dava importância a esta questão inconveniente $^{13}$. Do seu ponto de vista, ela era ociosa e não merecia exame; existia somente uma avaliação de possibilidades entre o rim móvel, o catarro crônico e uma afecção no ceco. Não se tratava da vida de Ivan Ilitch o que existia era uma discussão entre o rim móvel e a afecção no ceco. E o doutor resolveu esta discussão brilhantemente, na presença de Ivan Ilitch, a favor do ceco, fazendo também a observação de que o exame de urina poderia fornecer novos indícios, e que então o caso seria reexaminado. Tudo isto era exatamente o mesmo que o próprio Ivan Ilitch fizera mil vezes, com o mesmo brilhantismo, em relação a um acusado. De maneira igualmente brilhante,

Dossiê Literatura e Memória 
${ }^{14}$ Nem mesmo os parentes de Ivan Ilitch são capazes de compreender sua situação e sentir comiseração por isto. Todos evitavam seu parente moribundo, imersos em um universo simbólico que exclui os doentes e mortos da vida Somente Guerássim, interpretado aqui como símbolo, como veremos, da tradição campesina russa, o acompanhará durante o seu caminho rumo à morte. doutor fez o seu resumo e, com ar triunfannte, alegre até, lançou um olhar por gcima dos óculos, para o acusado. Ivan Ilitch concluiu desse resumo que as coisas iam mal, embora isto fosse indiferente ao médico e talvez a todos os demais. E esta conclusão impressionou Ivan Ilitch morbidamente, despertando nele um sentimento de grande comiseração por si mesmo e de profundo rancor contra aquele médico, tão indiferente a uma questão de tamanha importância (Tolstói, 2009, p. 37-38, grifos meus).

Transformações sociais engendram, como sabemos, novas expectativas e necessidades nas pessoas que experimentam seus resultados. No caso do homem perante à morte, vemos que a emergência e consolidação da medicina enquanto ciência e profissão legitimamente destinada ao tratamento da vida nos leva a configuração de uma nova necessidade: a expectativa e até a obsessão por diagnósticos. Rim móvel ou afecção no ceco, o importante é alcançar um diagnóstico para, assim, presentear o paciente com a dádiva da vida - certamente em troca de certa quantia, à preços justos.

Os germes da passagem que Ivan Ilitch experimenta durante o processo de sua morte podem ser encontrados no trecho supracitado. Se, em um primeiro momento, Ivan Ilitch compartilhava - talvez com certo receio - a crença coletiva na autoridade da medicina e seus métodos de postergação da morte e na ilusória imortalidade causada pelo recalcamento do inevitável, após essa penosa experiência nosso herói inicia um processo de passagem de um mundo a outro, através do qual, de maneira inconsciente, as atitudes e modos de vida e morte burgueses - ou ocidentais - são paulatinamente postos de lado. Ivan Ilitch toma consciência da solidão de sua morte e que ninguém, somente ele e, posteriormente, Guerássim -, compreende sua situação ${ }^{14}$. Assim começa o isolamento e a superação da morte de Ivan Ilitch.

\section{$O$ caso está na vida... E na morte}

No início, Ivan Ilitch se deixou levar pelas circunstâncias e, de fato, entrou no jogo de mentiras e omissões que marcam a retórica sobre a morte entre os que ele mantinha convívio - a "alta sociedade", fascinada com o ocidente e agentes ativos da cultura ocidental - principalmente francesa e alemã - na Rússia. Ele se enganava e deixava-se enganar pelos outros, mesmo sabendo, no fundo, que tudo estava errado e "ia mal". Nas palavras do narrador de Tolstói, "ele conseguia enganar-se, enquanto nada perturbava" (Tolstói, 2009, p. 40). O afastamento, o medo (ou talvez até horror) e a tentativa de postergar a morte a qualquer custo ainda eram, portanto, reproduzidos e fortalecidos pelos seus pensamentos e ações. Porém, ele já se encontrava entre dois mundos aparentemente - mas só aparentemente - excludentes.

Após sua consulta com o "médico famoso" a dor não cessou. Quando os remédios receitados pareciam começar a surtir efeito algum dissabor o afetava profundamente e a dor voltada e o derrubava. "Ele se enfurecia contra o infortúnio ou contra as pessoas que lhe causavam dissabores e que o assassinavam, e sentia que esse enfurecimento o estava matando" (Tolstói, 2009, p. 40). Uma confusão profunda - e, é claro, um também profundo desgosto e descrença - se enraíza em seu âmago e, em busca de

Dossiê Literatura e Memória

Arquivos do CMD, Volume 3 N.2. Ago/Dez 2015 
respostas para as suas "questões inconvenientes", Ivan Ilitch busca outros médicos e certos tratamentos, digamos, "alternativos", até se assustar com o seu próprio desespero. Neste período, Ivan Ilitch:

Procurou uma outra celebridade: esta segunda celebridade disse quase o mesmo que a primeira, mas formulou de maneira diferente as perguntas. E o aconselhar-se com esta celebridade apenas reforçou a dúvida e o medo de Ivan Ilitch. Um médico excelente, amigo de um amigo seu, classificou a doença de maneira completamente diversa e, embora tivesse prometido o restabelecimento, deixou Ivan Ilitch ainda mais confuso, em consequência das suas perguntas e suposições, e reforçou-lhe as suspeitas. Um médico homeopata fez um diagnóstico de todo diferente dos demais, e às escondidas de todos, Ivan Ilitch tomou durante cerca de uma semana o remédio que ele receitara. Mas passada uma semana, não tendo sentido nenhum alívio, e perdida a confiança quer em relação ao tratamento anterior, quer em relação a este, ficou ainda mais tristonho. De uma feita, uma senhora conhecida referiu-se a curas por meio de ícones. Ivan Ilitch surpreendeu-se ouvindo-a com atenção, procurando constatar a realidade do fato. Este caso assustou-o. "Será possível que eu me tenha enfraquecido tanto mentalmente? - disse de si para consigo. - Bobagem! É tudo tolice, não devo entregarme à hipocondria e, tendo escolhido determinado médico, preciso seguir estritamente o seu tratamento [...]" (Tolstói, 2009, p. 41)

Porém, "era fácil dizê-lo, mas impossível de executar". A dor não cessava, o seu hálito foi ficando asqueroso, seu apetite diminuía gradativamente e suas forças o deixavam. Sua condição era degradante, estava definitivamente se tornando, aos poucos, um cadáver. Ivan Ilitch começa a tomar consciência de que não pode mais mentir para si mesmo, pois nada estavam bem e ninguém, além dele, tinha a capacidade de compreender suas mazelas. Nas palavras de Tolstói

Não podia mentir para si mesmo: acontecia nele algo terrível, novo e muito significativo, o mais significativo que lhe acontecera na vida. E era o único a sabê-lo, todos os que o cercavam não compreendiam ou não queriam compreender isto, e pensavam que tudo no mundo estava como de costume. $\mathrm{E}$ isto atormentava Ivan Ilitch mais que tudo. As pessoas de casa (sobretudo a mulher e a filha, que estavam no mais aceso da vida social), ele via, não compreendiam nada e ficavam despeitadas porque ele estava tão triste e exigente, como se tivesse alguma culpa. Embora procurassem escondê-lo, ele via que constituía um estorvo [...] (Tolstói, 2009, p. 41-42, grifos meus).

A falsidade e o encobrimento da morte pelos que o cercam decorrente do recalcamento das coisas da morte é evidente. Todos vivem as suas vidas como de costume, nada parece ter mudado. A única coisa que todos têm a dizer sobre a doença de Ivan Ilitch é que ele deve seguir o tratamento à risca. Ora, para o nosso herói, como a passagem acima expõe, nada está como de costume e, pelo contrário, "acontecia nele algo terrível, novo e muito significativo"! Como todos ousam viver as suas vidas "como de costume"? De fato, isso irritava profundamente Ivan Ilitch, que começa a sentir ojeriza pela falsidade do ambiente social que o cerca - tanto em casa como no tribunal. Todos evitavam falar de sua condição enfermiça e tanto em casa como no tribunal as pessoas utilizavam diversas estratégias para contornar o assunto. No tribunal, por exemplo, Ivan Ilitch "ora tinha a impressão de que prestavam atenção nele como alguém que, em breve, deixaria uma vaga; ora 
os amigos começavam a caçoar carinhosamente da sua hipocondria" (Tolstói, 2009, p. 42). Todos o tratavam de maneira especial, como se ele não fosse mais um ser humano pleno, e estas piadas eufemísticas irritavam-no profundamente, "como se aquilo que havia de terrível, de assustador, de inaudito, que se instalara nele, que o sugava incessantemente e arrastava-o incoercivelmente para alguma parte, fosse o mais agradável pretexto para brincadeiras" (Tolstói, 2009, p. 42, grifo meu)

A interdição da morte nessas situações é evidente e Ivan Ilitch de fato tem consciência de que é um estorvo para todos. E por quê? Ora, como agentes individuais que buscam sempre a felicidade, as pessoas que o cercam não querem - e nem podem ter contato com a morte, a tristeza e a degradação física e mental de uma pessoa. Membros das classes altas da escala burocrática russa, os companheiros de outrora não tinham a capacidade - ou vontade -, como já foi sugerido, de comiserar-se pelas misérias de sua vida, pois ele estava, de fato, morrendo - mesmo que ainda não tenha se dado conta totalmente desse fato. Em um encontro com os amigos, após algumas rodadas de uíste, devido à condição enferma e irritadiça de Ivan Ilitch, “eles jantam e dispersam-se, e Ivan Ilitch fica sozinho, com a consciência de que a sua vida está envenenada, que ela envenena a vida dos demais e que este veneno não se enfraquece, mas penetra cada vez mais todo o seu ser" (Tolstói, 2009 , p. 43). Neste mundo onde a felicidade é uma obrigação e um imperativo nosso herói é posto cada vez mais de lado, caindo em um ostracismo inevitável e incontornável.
$\mathrm{O}$ aspecto físico de Ivan Ilitch começa a se degradar com o agravamento de sua doença e esta mudança se torna aparente aos olhos do leitor quando o nosso herói se encontra com seu cunhado, que chegara a pouco na cidade e se instalara em sua casa. Durante o breve encontro, dentro do escritório de Ivan Ilitch, o cunhado, depois de um segundo de absoluto silencio, "abriu a boca para soltar um 'ah', mas conteve-se". Ivan Ilitch desvendou todas as impressões de seu cunhado através desse período de silêncio seguido do "ah" embaraçado e indagou: "Então, eu estou diferente?" e, eufemisticamente, seu cunhado o responde, tentando encobrir suas verdadeiras impressões sem mentir claramente: "Sim... há uma diferença" (Tolstói, 2009, p. 44). Na realidade, a opinião de seu cunhado sobre o seu aspecto era bastante diferente desta sentença vazia e embaraçada. Às escondidas, trancado na sala de visitas ele diz para sua irmã: "Você não vê, mas ele é um homem morto, veja os seus olhos. Não têm luz. Mas o que é que ele tem?" (Tolstói, 2009, p. 45). A dúvida dos médicos volta à tona ninguém sabe ao certo o que ele tem. O que de fato existe é uma discussão sobre o rim móvel e uma afecção no ceco.

Diante do fracasso completo das modernas técnicas médicas, Ivan Ilitch compreende o que realmente estava ocorrendo dentro de seu corpo. Ele compreende o que o estava envenenando e sugando a sua força vital: a morte. A dor não cessava, as coisas só pioravam. Completamente dominado pelas dores e pelo gosto asqueroso na boca, nosso herói, subitamente, começa a enxergar as coisas de uma maneira completamente diferente, transformando, 
${ }^{15}$ Me refiro aqui à noção de drama social proposta por Victor Turner (2008), que envolve quatro fases: "quebra de uma regra ou valor; crise; "quebra de uma regra ou valor; crise;
ação reparadora; re-integração ou reconhecimento do cisma" (Cavalcanti, 2007) também, a sua costumeira forma de encarar tudo o que estava acontecendo dentro de si. Uma primeira conclusão surge dessa epifania:

O ceco! O rim [...]. o caso não está no ceco, nem no rim, mas na vida e... na morte. Sim, a vida existiu, mas eis que está indo embora, embora, e eu não posso detê-la. Sim. Para quê me enganar? Não é evidente para todos, com exceção de mim, que estou morrendo, e a questão reside apenas no número de semanas, de dia, talvez seja agora mesmo? Existiu luz, e agora é a treva. Eu estive aqui, e agora vou para lá! Para onde? (Tolstói, 2009, p. 47).

Depois de um período de gestação, uma transformação intensa toma forma no âmago de Ivan Ilitch, ele compreende tudo o que está acontecendo dentro de si e concebe, pela primeira vez, a ideia de que está morrendo e que este é um processo inevitável. Não obstante, o seu medo da morte - característico do modelo de "morte interdita" (Ariès, 1989b) - continua forte e o domina completamente, levando-o ao desespero. "Ivan Ilitch via que estava morrendo, e o desespero não o largava mais. Sabia, no fundo da alma, que estava morrendo, mas não só não se acostumara a isto, como simplesmente não o compreendia, não podia de modo algum compreendê-lo" (Tolstói, 2009, p. 49). Aqui ocorre uma intensificação do drama experienciado pela personagem ${ }^{15}$. Para compreender essa nova situação e aceitar o inevitável, o processo de negação dos antigos valores - que, diga-se de passagem, ainda estão, de certa maneira, enraizados em sua psique - deve se completar. Nesse momento, a tensão entre a aceitação da morte e os "velhos pensamentos" de Ivan Ilitch vigora. A sua morte simplesmente não é possível, porém, a realidade começa a se impor - ela sempre "voltava e estacava diante dele", sob a forma da morte - e a morte começa a adentrar a densa floresta de seus pensamentos:

E ele convocava, um após o outro, pensamentos que substituíssem aquele, na esperança de encontrar neles apoio. Tentava voltar aos velhos caminhos de pensamento, que ocultaram para ele anteriormente ideia da morte. Mas, fato estranho, tudo o que antes ocultava, escondia, anulava a consciência da morte, não podia mais ter este efeito. Ultimamente, Ivan Ilitch passava a maior parte do tempo nessas tentativas de restabelecer os primitivos caminhos do sentimento que ocultava a morte. As vezes dizia consigo: "Vou ocupar-me do serviço, bem que ele já me fez viver". E ia para o tribunal, repelindo todas as dúvidas. [...] Mas de repente, em meio à sessão, a dor do lado iniciava, sem dar nenhuma atenção ao desenvolvimento do caso judiciário, iniciava o trabalho com o seu caso, aquele trabalho sugador. Ivan Ilitch prestava atenção, enxotava o pensamento a respeito dela, mas ela continuava a sua faina, e ela vinha e parava bem diante dele, e olhava-o, e ele petrificava-se, o fogo apagava-se em seus olhos, e ele começava de novo a interrogar-se: "Será possível que somente ela seja verdade?". E os seus colegas e subalternos viam com espanto e desgosto que ele, um juiz tão brilhante sutil, confundia-se, errava. Ele se sacudia, esforçavase em voltar a si, conduzia a sessão de qualquer maneira até o fim e regressava para casa, com a triste consciência de que a sua função judiciária não podia mais, como outrora, esconder dele aquilo que ele queria esconder; que não podia livrar-se dela por meio da função judiciária. E o pior de tudo era que ela atraía para si, não para que fizesse algo, mas unicamente para que a olhasse, bem nos olhos, olhasse-a e se atormentasse indescritivelmente, sem fazer nada (Tolstói, 2009, p. 50-51) 
${ }^{16}$ Tolstói foi um grande admirador e observador dos costumes campesinos, assim como um agitador cultural crítico às transformações que assolavam a Rússia. De caráter messiânico, Tolstói chegou a formar - talvez indiretamente - diversos seguidores, os "tolstonianos". Suas posições acerca do amor à vida e aos homens, da valorização dos modos de vida campesinos o levaram, aos olhos de alguns, à condição de profeta místico. Romain Rolland, um dos biógrafos de Tolstói, escreveu sobre o autor: "Um profeta é um utopista. [...] Desde sua vida terrestre participa da vida eterna. Que essa aparição nos tenha sido concedida, que víssemos entre nós o último dos profetas, que o maior dos nossos artistas tivesse esta auréola na fronte esse fato, parece-me, é mais original e de importância maior para o mundo que uma religião a mais ou uma nova filosofia" (Rolland apud Rónai, p. 87, 2009). Um dos projetos experimentais supracitados foi descrito por Tolstói em Quem deve aprender a escrever com quem, as crianças camponesas conosco ou nós com as crianças camponesas?, ensaio disponível em Gomide (2013).

Sobre as obshchinas ver Gomide (2013), Frank (1992) e Berlin (1988).

Dossiê Literatura e Memória

Arquivos do CMD, Volume 3 N.2. Ago/Dez 2015
Através do horror diante do inevitável e o afastamento deste, elementos cabais do processo de recalcamento da morte experimentado por Ivan Ilitch durante toda a sua vida, percebemos a ideia ocidental de que os indivíduos são unidades invariavelmente distintas umas das outras e, a partir disso, Ivan Ilitch costumava pensar - e, neste momento da novela, ainda pensa - que era um indivíduo pleno, diferente de todos, e que as regras da natureza poderiam servir para todos, menos para ele. Assim repousava nosso herói em sua ilusória imortalidade:

O exemplo do silogismo que ele aprendera na Lógica de Kiesewetter: Caio é um homem, os homens são mortais, logo Caio é mortal, parecera-lhe, durante toda a sua vida, correto somente em relação a Caio, mas de modo algum em relação a ele. Tratava-se de Caiohomem, um homem em geral, e neste caso era absolutamente justo; mas ele não era Caio, não era um homem em geral, sempre fora um ser completa e absolutamente distinto dos demais; ele era Vânia, com mamãe, com papai, com Mítia e Volódia, com os brinquedos, o cocheiro, a babá, depois com Kátienka, com todas as alegrias, tristezas e entusiasmos da infância, da juventude, da mocidade. Existiu porventura para Caio aquele cheiro da pequena bola de couro listada, de que Vânia gostara tanto?! Porventura Caio beijava daquela maneira a mão da mãe, acaso farfalhou para ele, daquela maneira, a seda das dobras do vestido da mãe? Fizera um dia tanto estardalhaço na Faculdade de Direito, por causa de uns pirojki? Estivera Caio assim apaixonado? E era capaz de conduzir assim uma sessão de tribunal? (Tolstói, 2009, p. 49).

Considerando isso, Ivan Ilitch ainda não completara sua passagem, sua crise se intensificara, inserindo-o numa situação de liminaridade e solidão, o que faltava então para essa profunda transformação de si nos derradeiros dias de sua vida? A resposta está em seu copeiro, Guerássim, ou melhor, na relação que se estabelece entre as duas personagens. Para concluirmos a investigação sobre essa tão especial transformação em nosso herói, uma ou duas palavras deverão ser dedicadas a este reencontro.

\section{A transvaloração do herói positivo: "o aspecto russo"}

Ivan Ilitch encontrou em Guerássim seu último consolo. Assim, nosso herói se agarra ao seu copeiro que, por sua vez, o acolhe e cuida de seu patrão "de modo amoroso e com eficiência [...], dentro da milenar tradição campesina de cuidados no fim da vida" (Floriani, 2013, p. 401). Guérassim representa, nesta novela, o mujique russo, tão admirado por Tolstói que, não obstante sua origem social aristocrata, mantinha projetos educadores junto aos mujiques e suas crianças em sua propriedade em Iásnaia-Poliana onde viveu durante meio século ${ }^{16}$. Ele simboliza a resistência da cultura tradicional russa, considerada "arcaica" pela ala "ocidentalizante" da intelligentsia do país e materializada nas comunidades campesinas tradicionais chamadas obshchinas ${ }^{17}$, modelo de sociedade para os socialistas utópicos e eslavófilos. Através da comunhão cristã estabelecida na relação entre Guerássim e Ivan Ilitch o nosso herói inicia a última fase de seu drama: a re-integração. Porém, esta transformação não o re-integra ao mundo da alta sociedade russa, mas o insere em um novo contexto, marcado por relações de compaixão e aceitação perante a morte, sempre presente nas vidas das pessoas - o que não exclui a agonia e medo do morrer. Esta drástica mudança começa pela 
rejeição e ojeriza pelo mundo dos seus, causadas pela falta de compreensão destes de seus intensos sofrimentos e pelo isolamento decorrente desta incompreensão.

Assim, durante a intensificação da sua situação enfermiça, os médicos prescreveram certos cuidados especiais, degradantes para Ivan Ilitch, que sofria amargamente "por causa da sujeira, da indecência e do cheiro, da consciência de que outra pessoa devia ter participação naquilo", porém, da insipidez de sua situação surgiu sua salvação, pois "foi justamente nessa desagradável ocupação que surgiu um consolo para Ivan Ilitch", pois "quem sempre vinha levar o vaso era o ajudante de copeiro Guerássim” (Tolstói, 2009, p. 53). Norbert Elias, em A solidão dos moribundos, argumenta que, nos momentos derradeiros do moribundo, o afeto e a aproximação dos entes próximos com o moribundo são cruciais. Com a negligência de seus amigos e parentes próximos, o único que conseguiu comiserar-se de sua situação enfermiça e lhe deu a devida atenção e afeto nos derradeiros momentos de sua vida, de fato, foi este "mujique jovem, limpo, ressumando frescor", que "estava sempre alegre, radiante" (Tolstói, 2009, p. 53) mesmo cumprindo uma função tão degradante. Depois de todos os desgostos que sofrera, Ivan Ilitch "sentia-se tão bem com ele, que não queria deixá-lo” (Tolstói, 2009, p. 54). Guerássim foi, portanto, uma Providência na morte de Ivan Ilitch.

Ivan Ilitch não suportava mais o engodo que o cercava e, com efeito, o influenciava fortemente, fazendo com que ele entrasse no jogo de mentiras que envenenava o seu morrer. $\mathrm{O}$ recalque dos seus parentes e colegas próximos o irritava a ponto da cólera. Como diz o narrador de Tolstói: "Essa mentira ao seu redor e nele mesmo envenenou mais que tudo os últimos dias da vida de Ivan Ilitch" (Tolstói, 2009, p. 57). Além disso, o que mais o atormentava nesses últimos momentos de vida era o fato de ninguém se compadecer dele. Somente Guerássim, com outra mentalidade, outra cultura, pôde atenuar a sua dor:

O sofrimento maior de Ivan Ilitch provinha da mentira, aquela mentira por algum motivo aceita por todos, no sentido de que ele estava apenas doente e não moribundo, e que só devia ficar tranquilo e tratarse, para que sucedesse algo muito bom. Mas ele sabia que, por mais coisas que fizessem, nada resultaria disso, além de sofrimentos ainda mais penosos e morte. E esta mentira atormentava-o, atormentava-o o fato de que não quisessem confessar aquilo que todos sabiam, ele mesmo inclusive, mas procurassem mentir perante ele sobre a sua terrível situação, e o obrigassem-no a tomar também parte nessa mentira. [...] Via que ninguém haveria de compadecer-se dele, porque ninguém queria sequer compreender a sua situação. Guerássim era o único a compreendê-la e a compadecer-se dele. Por isso Ivan Ilitch sentia-se bem unicamente na presença de Guerássim. [..] Guerássim era o único a não mentir, tudo indicava que era também o único a compreender do que se tratava, que não considerava necessário escondê-lo, e simplesmente tinha pena do patrão fraco, em vias de se acabar (Tolstói, 2009, p. 56, grifo meu).

Com efeito, esta personagem compartilha ideários distintos em relação às "classes altas" da Rússia, aburguesadas e europeizadas. Guerássim carrega uma tradição campesina secular, comunitária e fortemente religiosa, calcada no amor cristão. Logo no início da novela percebemos a discrepância entre o mundo de

Dossiê Literatura e Memória

Arquivos do CMD, Volume 3 N.2. Ago/Dez 2015 
Guerássim e o de seus "superiores", durante o breve diálogo entre ele e Piotr Ivânovitch. Ao ser cumprimentado por Guerássim nas exéquias de Ivan Ilitch, Piotr Ivânovitch diz, já de saída:

\begin{abstract}
- E então, Guerássim, irmão? - perguntou Piotr Ivânovitch, a fim de dizer algo. - Sente pena?

- É a vontade de Deus. Iremos todos para lá - disse Guerássim, arreganhando os dentes brancos, cerrados, de mujique, e, como uma pessoa em pleno trabalho intensivo, abriu rapidamente a porta, chamou o cocheiro, ajudou Piotr Ivânovitch a sentar-se e deu um pulo de volta, com o ar de quem estivesse pensando no que mais tinha a fazer. (Tolstói, 2009, p. 17)
\end{abstract}

Uma tensão subjacente entre dois mundos emerge desse curto, porém significativo, diálogo. De um lado, o mundo da "morte interdita", onde os mortos vivem em exílio no submundo da mente humana. Do outro, o mundo da "morte domesticada", onde a ideia da morte convive religiosamente com os vivos se não em harmonia, ao menos com forte presença - o medo e horror perante a morte de fato existe, mas não o recalque. Esta justaposição tensionada permeia toda a narrativa de Tolstói, sendo crucial para este esforço interpretativo a compreensão destes dois mundos distintos, mas não mutuamente excludentes.

Assim, o acontecimento que faltava no processo de passagem de nosso herói, de fato, era o encontro amigável com essa tradição, esse passado do povo russo tão negligenciado pelas "classes altas" do país. O encontro entre Ivan Ilitch e o universo campesino culmina no movimento renovador que surge em seu âmago. Não obstante, esse processo se desenrola sobre o prisma russo, isto é, usando uma expressão de Dostoiévski, através do "aspecto russo", que corresponde, segundo o escritor, a uma forma propriamente russa de ver e pensar o mundo que influenciava inclusive no processo de assimilação de ideias europeias e mobilização prática destas. Sobre esse "aspecto russo", trabalhado por Dostoiévski em um artigo de 1873, na revista $O$ cidadão, editada pelo próprio Dostoiévski, Joseph Frank declara:

Dostoiévski tinha, pois, consciência aguda da maneira pela qual as ideias europeias sofriam transformação quando passavam por mentes russas e eram aplicadas a problemas russos. Suas consequências mais extremas seriam inevitavelmente inferidas; seriam acreditadas e aceitas com fervor religioso, e a elas seria imediatamente dada uma aplicação prática. Como observa Dostoiévski, Mill, Darwin e Straus eram homens que, sem dúvida, amavam a humanidade, mas na Rússia suas ideias tinham levado diretamente ao caso Nietcháiev, no qual um jovem estudante que desejara abandonar uma organização revolucionária secreta fora assassinado a sangue frio para segurar os outros através do terror. Ideias que na Europa apenas suscitavam controvérsias eruditas ou no máximo algumas sérias dúvidas nas profundezas de consciências perturbadas, na Rússia poderiam, provavelmente iriam, resultar em brutalidade física (Frank, 1992, p. 81-82).

Este "aspecto russo" decorre do fato de que ideias e atitudes nunca são mecanicamente assimiladas e transpostas em contextos diferentes, sendo antes reinterpretadas e reinventadas que puramente assimiladas. No drama de Ivan Ilitch não chegamos a essas "consequências mais extremas", porém, este "aspecto russo" que forma, com efeito, um prisma para a influência externa, nos é interessante. Com efeito, Ivan Ilitch, durante toda a sua vida, fora uma pessoa ordinária e decente, seguindo padrões preestabelecidos

Dossiê Literatura e Memória

Arquivos do CMD, Volume 3 N.2. Ago/Dez 2015 
${ }^{18}$ Expressões russas que significam "perdoe-me" e "deixe-me passar", respectivamente por sua posição social e, consequentemente, reproduzindo formas de vida fortemente influenciadas pelas modas europeias. Não obstante, esses mesmos modos de viver, pensar e sentir, interpretados e incorporados por ele no final de sua vida e em relação com a nova luz de sua vida representada por Guerássim e a tradição russa campesina toma formas distintas. Dessa maneira, o individualismo de Ivan Ilitch, ao entrar em contato profundo com Guerássim, vai se dissolvendo em um tipo de humanismo, uma ideia de humanidade comum, e o racionalismo hermético de seu passado jurídico se metamorfoseia e culmina em uma nova forma de razão, através da qual ele toma uma posição nos seus momentos derradeiros e escolhe morrer de maneira diferente, sem horror e, principalmente, sem medo. Ivan Ilitch escolhe aceitar a morte, a mesma morte que lhe encarava friamente nos momentos de desespero.

O processo de transformação de nosso herói se completa no derradeiro instante de sua vida, a passagem se completa. Os dois mundos em tensão dentro de si entraram em uma relação simbiótica e dialética, na qual a síntese é a reinvenção pela tensão. Nem juiz de instrução, nem mujique, mas o resultado real dessa relação nas circunstâncias da morte. Marcadamente ideológico, o final deste drama é a salvação pelo amor e compaixão, características do discurso profético do velho Tolstói.

Depois de três dias de profundo tormento Ivan Ilitch toma clara consciência de sua condição irrefreável e completa sua metamorfose. Sofrendo duras dores, cercado pelos parentes mais próximos, tenta dizer prosti, mas acaba dizendo propusti ${ }^{18}$. O simbolismo é importante, pois guia Ivan Ilitch da culpa por sua morte até a vontade de potência rumo ao inevitável que, se antes era inaudito, agora já é claro e expresso - ao menos para ele. Por fim, o drama do nosso herói termina no auge de sua passagem: sua dor se esvai, Ivan Ilitch a procura, mas não a encontra, "procurou o seu habitual medo da morte e não o encontrou. Onde ela está? Que morte? Não havia nenhum medo, porque também a morte não existia" (Tolstói, 2009, p. 76). A morte de Ivan Ilitch é a passagem de um mundo para outro, de um morrer inaudito, espantoso e sobretudo individualizado, para uma morte presente e compartilhada.

\section{Considerações finais}

Em Literatura e sociedade, Antonio Candido argumenta que:

$$
\begin{aligned}
& \text { A arte, e portanto a literatura, é uma transposição do } \\
& \text { real para o ilusório por meio de uma estilização } \\
& \text { formal, que propõe um tipo arbitrário de ordem para } \\
& \text { as coisas, os seres, os sentimentos. Nela se combinam } \\
& \text { um elemento de vinculação à realidade natural ou } \\
& \text { social, e um elemento de manipulação técnica, } \\
& \text { indispensável à sua configuração, e implicando uma } \\
& \text { atitude de gratuidade (Candido, 2011, p. 63). }
\end{aligned}
$$

Dessa maneira, o autor argumenta que a obra de arte não é um produto puramente social, tampouco o resultado de um impulso individual, decorrendo antes de um "movimento dialético que engloba a arte e a sociedade num vasto sistema solidário de influências recíprocas" (Candido, 2011, p. 34). Esta relação 
solidária entre arte e sociedade resulta numa unidade inevitável entre forma e conteúdo. Decorre desta perspectiva o fato das obras de arte cristalizarem, através de manipulações técnicas propriamente artísticas, elementos ou fragmentos da vida social, produzindo, portanto, uma obra que formaliza, sensível e expressivamente, tensões sociais, valores, ideologias e mentalidades. A obra de arte se transforma, portanto, além de origem de prazer e apreciação estéticos, fonte de análise social e cultural de uma sociedade. "Muito mais que um reflexo" social, sob essa perspectiva a literatura se apresenta, como declarou Michel Vovelle numa comunicação em 1980, como uma fonte indispensável à história das mentalidades ou ideias, incluindo nesta categoria a história da morte:

O circuito pela literatura me parece, enquanto historiador das mentalidades, um meio não somente útil, mas indispensável para reintroduzir no caminho do tempo curto, uma História que tem uma tendência forte demais para ceder às tentações de uma História imóvel, mergulhando com enlevo em uma etnografia, histórica ou não, justamente quando a dimensão do tempo curto corresponde ao da História que se agita com frêmitos de sensibilidade, que são muito mais que a espuma fugidia dos dias (Vovelle, 1987, p. $64)$.

Em vida, Tolstói tinha uma espécie de obsessão pela morte, sintoma que se reflete em sua obra, chegando a tornar-se, nas palavras de Paulo Rónai (2009), “de certo modo, um especialista da morte na literatura". De acordo com o estudioso:

Depoimentos de parentes e amigos confirmam as confidências do romancista: a morte era para ele uma obsessão. Segundo relata seu filho Iliá, Tolstói fazia questão de conhecer as menores particularidades do passamento de seus amigos, dando a impressão de ter à morte um verdadeiro culto, uma espécie de amor. Outro filho, Lev, ratifica o testemunho do irmão, embora dando outra explicação daquela ideia fixa: 'Embora durante trinta e cinco anos não deixasse de falar um só dia na morte, meu pai não a desejava, temia-a e fazia tudo para adiá-la'. Gorki informa que, diante dele e de Tchekhov, Tolstói afirmou certa vez que, 'depois que um homem aprende a pensar, pensa sempre na própria morte, pouco importa em que estej pensando. Todos os filósofos fizeram assim. E que verdade pode haver uma vez que existe a morte?'” (Rónai, 2009, p. 89-90).

Este impulso idiossincrático pode ter levado o autor a tratar abertamente da morte em sua obra, mas só a observação minuciosa e crítica da vida social e formalização desta na obra literária possibilitaram Tolstói a realizar uma obra tão importante tanto para a história da literatura quanto para a história das ideias ou mentalidades (Vovelle, 1987). Jogo dialético entre vida social e impulsos individuais, A morte de Ivan Ilitch apresenta e unifica elementos relacionados tanto a tensões sociais quanto a obsessões e idiossincrasias do autor.

De fato, esta obra paradigmática expressa, a sua maneira, um momento de turbulência entre os russos. Nessa época, a literatura era considerada uma importante arena que veiculava diversos discursos e debates na esfera pública russa, principalmente devido à censura do regime czarista e à importância dos periódicos que publicavam, além de ensaios críticos e políticos, obras de autores como Tolstói, Dostoiévski e Turgueniev. A literatura, 
portanto, "era entendida como o principal meio de conhecimento da vida social russa" (Gomide, 2013, p. 18). No debate entre eslavófilos e ocidentalizantes da intelligentsia russa, subjaz uma tensão entre modos de vida e mentalidades e atitudes acerca da morte e do morrer, consideradas neste texto a partir do choque entre a morte pública e domesticada e o modelo da morte medicalizada e solitária dos hospitais e leitos.

Dessa maneira, esta obra expressa um momento de transição do morrer na história russa, no qual ambas as formas ou modelos de morte coexistem de modo tensionado, sendo veiculados por discursos e atitudes de pessoas pertencentes a classes sociais distintas. Foco analítico deste artigo, o estabelecimento da medicalização da morte constitui um dos eixos do processo de ocidentalização da Rússia, movimento que, como apontei, não foi mecânico, mas tensionado e criativo. Entre a morte pública e domesticada dos camponeses russos e o morrer individualizado e interdito da alta sociedade, Tolstói realiza uma justaposição conflituosa entre dois mundos da morte, sublimada no drama de Ivan Ilitch. Passando de um contexto para o outro, o herói da novela conjuga, através de suas dúvidas e angústias, fragmentos de dois universos simbólicos distintos.

Observador perspicaz e admirador da vida campesina russa, além de agitador cultural e "juiz cada vez mais intransigente dos costumes" (Rónai, 2009, p. 86), Tolstói "transpõe para o ilusório" fragmentos do processo de ocidentalização da Rússia, colocando a solidariedade camponesa e o amor cristão como solução dos desgostos e angústias de Ivan Ilitch que, após uma espécie de educação sentimental, aprende a morrer. Expressão sensível de um processo de transição da morte e do morrer, a obra de Tolstói traz tensões cruciais tanto para a compreensão das atitudes em relação a morte, como para o entendimento das sensibilidades perante a vida.

\section{Referências Bibliográficas}

ARIÈS, Philippe. O homem diante da morte. Rio de Janeiro: Francisco Alves, v.1, 1989a

Sobre a história da morte no ocidente: desde a Idade Média. Lisboa: Editorial Teorema, 1989b.

“Uma antiga concepção de além”. In: BRAET, Herman;

VERBEKE, Werner. A morte na Idade Média. São Paulo: Edusp, 1996.

BERLIN, Isaiah. Pensadores russos. São Paulo: Companhia das Letras, 1988.

BOURDIEU, Pierre; CHARTIER, Roger. $O$ sociólogo $e$ o historiador. Belo Horizonte: Autêntica Editora, 2012.

CANDIDO, Antonio. Literatura e sociedade. Rio de Janeiro: Ouro sobre Azul, 2011.

CAVALCANTI, Maria Laura Viveiros de Castro. "Drama Social: Notas sobre um tema de Victor Turner". Cadernos de campo, n. 16, p. 127-137, 2007.

COSTA, Jurandir Freire. Ordem médica e norma familiar. Rio de Janeiro: Edições Graal, 1999.

DIDION, Joan. $O$ ano do pensamento mágico. Rio de Janeiro Nova Fronteira, 2006 
DOSTOIEVSKI, Fiódor. Correspondências (1838-1880). Porto Alegre: 8Inverso, 2011.

ECO, Umberto. Os limites da interpretação. São Paulo: Editora Perspectiva, 2010.

ELIAS, Norbert. A solidão dos moribundos. Rio de Janeiro: Zahar, 2001.

. Envelhecer e morrer. In: A solidão dos moribundos. Rio de Janeiro: Zahar. 2001.

. O processo civilizador. Rio de Janeiro: Zahar, v1, 1994.

FLORIANI, Ciro Augusto. Moderno movimento hospitace: kalotanásia e o revivalismo estético da boa morte. Disponível em: http://revistabioetica.cfm.org.br/index.php/revista_bioetica/article/v iewFile/849/919, último acesso em 11/04/2014.

FRANK, Jospeh. Pelo prisma russo. São Paulo: Edusp, 1992.

FREUD, Sigmund. Luto e melancolia. São Paulo: Cosac Naify, 2011.

GOMIDE, Bruno Barreto (org.). Antologia do pensamento crítico russo (1802-1901). São Paulo: Editora 34, 2013.

GORER, Geoffrey. The pornography of death. Disponível em: http://www.romolocapuano.com/wp-

content/uploads/2013/08/Gorer.pdf, último acesso em 12/04/2014. GORKI, Maksim. Minhas universidades. São Paulo: Cosac Naify, 2007.

LATOUR, Bruno. Jamais fomos modernos: ensaio de antropologia simétrica. Rio de Janeiro: Editora 34, 1994.
MAUSS, Marcel. A expressão obrigatória dos sentimentos (rituais fúnebres australianos). In: Figueira, S (org.). Psicanálise e Ciências Sociais. Rio de Janeiro: Livraria Francisco Alvez, 1974.

OEXLE. Otto Gerhard. A presença dos mortos. In: BRAET, Herman; VERBEKE, Werner. A morte na Idade Média. São Paulo: Edusp, 1996.

RÓNAI, Paulo. "Sobre Tolstói e a morte de Ivan Ilitch". In: TOLSTÓI, Lev. A morte de Ivan Ilitch. São Paulo: Editora 34, 2009.

SCHWARZ, Roberto. As ideias fora do lugar. In: Ao vencedor as batatas. São Paulo: Editora 34, 2000.

TOLSTÓI, Lev. Anna Kariênina. São Paulo: Cosac Naify, 2013. . A morte de Ivan Ilitch. São Paulo: Editora 34, 2009.

Quem deve aprender a escrever com quem, as crianças camponesas conosco ou nós com as crianças camponesas? In: GOMIDE, Bruno Barreto (org.). Antologia do pensamento crítico russo (1802-1901). São Paulo: Editora 34, 2013.

TURNER, Victor. 2008. Dramas, campos e metáforas. Rio de Janeiro: EdUFF.

VOVELLE, Michel. As almas do purgatório ou o trabalho de luto São Paulo: Unesp, 2010

_. Ideologias e mentalidades. São Paulo: Editora Brasiliense, 1987. 